\title{
HOXB9 Gene
}

National Cancer Institute

\section{Source}

National Cancer Institute. HOXB9 Gene. NCI Thesaurus. Code C101590.

This gene is involved in both embryonic development and transcriptional regulation. 